\title{
ASEAN ECONOMIC COMMUNITY 2015: NEEDS ANALYSIS OF UNIVERSITAS INDONESIA'S ENGINEERING STUDENTS
}

\author{
Lavinia D.W. Araminta \\ Sisilia S. Halimi \\ Universitas Indonesia \\ sshalimi@hotmail.com
}

Article received: 15 April 2015

Final proof received: 26 June 2015

\begin{abstract}
Prior to the ASEAN Economic Community in the end of 2015, one of the keys for Indonesian engineers to outrank engineers from other ASEAN countries is mastering English language skills. This study aims at analyzing the English needs of undergraduate engineering students at Universitas Indonesia. Questionnaires and semi-structured interviews were used as the data collection methods. The questionnaires were spread to 111 alumni and 150 students from the Faculty of Engineering. The interviews were conducted with HRD from a multinational company, HRD from a local company, three heads of departments, and two lecturers from the Faculty of Engineering. The research reveals that students' needs of English language learning are considered not as high as their needs of English language use. The recommendation given to the Faculty of Engineering is to conduct an optional course on English for Professional Purposes, and the course is to be handled by professional English teachers helped by the lecturers from the Faculty of Engineering.
\end{abstract}

Keyword: needs analysis; English for Professional Purposes, target situation analysis

The ASEAN countries have committed themselves to write a new history in the development of the pattern of economic cooperation by signing the declaration of the ASEAN Economic Community (AEC) at the 17th ASEAN Summit in Singapore in November 2007 (Hidayat, 2008, pp. 1-3). AEC is expected to enhance the trading activity among members (intra-trade), benchmarking the success of the European Union and the African Economic Community. To be an equal region in economic development and be integrated in the global economy, ASEAN will establish a single market with five major components, namely: 1) the free flow of goods, 2 ) the free flow of services; 3 ) the free flow of investment, 4) the free flow of capital, and 5) the free flow of skilled labor (Hidayat, 2008, pp. 1-3).

Regarding the fifth component, Indonesia faces both opportunities and challenges. On one hand, the liberalization of services and the strengthening of the current skilled workforce will open up more jobs. In addition, to support the labor movement, the Ministers of Economy in ASEAN countries have agreed on Mutual Recognition Arrangement (MRA) for several fields of services, including engineering, nursing, architectural, surveying qualification, medical personnel (doctors and dentists), and accounting. Among these fields, the MRA on Engineering Services, which was approved on December 9, 2005 in Kuala Lumpur, was the first one agreed upon and applied. The agreement aims to establish mechanisms in achieving professional certification and standardization in each field by acknowledging the differences among ASEAN countries in terms of education, training, experience, and licensing requirements for professionals who want to practice their services ("Ministry of Trade", n.d.).

On the other hand, Indonesia will face challenges as Indonesian college graduates will have to struggle to win the competition against other professional workers from other ASEAN countries. As a result, competition in the workplace will become more stringent due to the entry of professionals from other ASEAN countries to Indonesia. In a seminar and discussion on the theme "ASEAN Services Sector Liberalisation: Threat or Opportunity for Students" in 2013, held at Universitas Indonesia, Makmur Keliat, Ph.D., a researcher from UI's ASEAN Study Center, said that although Indonesia was the largest contributor to the labor force in ASEAN, Indonesia's labor force quality was still poor, especially in terms of proficiency in English. He added that the use of English by skilled workers or professionals in Indonesia was only around 44 percent, and it could be a real obstacle in the field (as cited in “Bahasa Inggris," 2013).

This notion is supported by a study conducted by Education First (2012) on the English Language Proficiency Index (English Proficiency Index) which shows some facts which are quite alarming. In the report, Indonesia was ranked 27th among the countries in Asia with a score of 53.31 and was categorized as having low proficiency in English. Although this study is very general by not specifying variables, such as age, education level, and residence, it can be generally assumed that the English proficiency of Indonesians is still below Singapore (ranked 12th) and Malaysia (ranked 13th), regardless of the status of English as the national language and the official language in both countries. Apparently, language ability becomes a crucial aspect in the professional world, particularly in the scope of work 
that has cross-cultural encounters among its workers. Riemer (2007, p. 89) even said that English skills could be career-enhancer for engineers. Thus, the fact that Indonesian workers still lack good proficiency in English can bring concern for the government and the workers themselves.

However, although this problem has been a concern in Indonesia, there have not been any specific researches about it, such as the evaluation of Indonesian workers' English skills or the most effective ways to solve the problem. To be more specific, there has been limited discussion on how AEC 2015 is correlated to the needs for learning English for Indonesian workers. Compared to other countries in ASEAN, they seem to be more prepared and have been working on studies regarding the correlation between English language competence and the labor market under the circumstance of AEC 2015. One of them is a paper written by two Thai educators, Saraithong and Chancharoenchai (2012) titled "The Determinants of New Coming Workers' English Proficiency in the ASEAN Economic Community: A Case of Thai Vocational Students". The paper uses needs analysis to provide an understanding of how ASEAN Economic Community will affect the Thai labors' working prospect in regards to their English capacity. Saraithong \& Chancharoenchai $(2012$, p. 3) said that "In Thailand, once the AEC takes effect, the issue of English language proficiency will turn into a sensitive issue for Thai labor. It could determine workers' chances of retaining a present job or getting a new job". Indonesian researchers have also done similar research by using needs analysis, for example, Marwan (2009) who wrote "ESP Teaching Challenges in an Indonesian Vocational Higher Institution". This article shows some challenges in ESP teaching at State Polytechnic of Pontianak and proposes useful recommendations for ESP teachers and teaching system at that institution. However, it does not address professional communication in engineering and does not refer to AEC 2015 as the background issue.

The lack of researches on that particular issue becomes a background why this study was conducted. The problem of Indonesian workers' low English proficiency in facing AEC 2015 was not seen from the eyes of economics or international relations but from linguistics' point of view. Instead of mapping the implications of AEC 2015 for our labor force, this study tries to give solutions by paying attention closely to what English skills should be taught to Indonesian workers in order to be more proficient in English. To find the answers, needs analysis is used as the approach of this research. As expressed by Alshumaimeri (2009, pp. 2-7), needs analysis is conducted so that students can identify their needs for learning ESP better and to help the relevant stakeholders to set goals and ESP syllabus to be right on target.

A number of researches on English needs analysis have been carried out, both by discussing theories and by conducting needs analysis practically in the field. The article "A Framework for Investigating Learner Needs: Needs Analysis Extended to Curriculum Development" by Kaewpet (2009) gives a clear framework of doing a needs analysis in engineering field by looking at some theories, from the sociolinguistic model to the task-based approach. The article aims to investigate the English for Specific Purposes (ESP) needs of Thai engineering students who will study ESP in a Foreign Language (EFL) environment. Kaewpet (2009, pp. 209-210) said the following:

\begin{abstract}
"It is clear from the review of ESP and engineering literature that the engineering profession significantly requires English as a means of communication. Multicultural work practices increasingly demand that engineers are equipped with enhanced soft-skill proficiency, specifically, foreign language ability, communication confidence and cross-cultural experience"
\end{abstract}

In the end, the findings of this study were expected to provide pragmatic and effective recommendations for the relevant stakeholders to prepare engineering undergraduates of Universitas Indonesia to be more competent in English language skills towards the coming ASEAN Economic Community in 2015.

\section{METHOD}

As a pilot research in this particular topic, the research was limited to the needs for learning English for engineering students at UI. Engineering field is selected as the MRA on Engineering Services was the first ratified agreement. Meanwhile, Universitas Indonesia (UI) was chosen as the scope of the study because UI has proclaimed itself to be a world-class university and is committed to equip its students with global competencies.

Interviews were conducted with: 1) A representative from a multinational and a local companies, the Head of HRD (Human Resources Development) of Hitachi Asia Ltd. Jakarta Office and the recruitment and Training officer of PT Wijaya Kusuma Contractors, to understand the company's expectations of how competent Indonesian workers should be in English skills; and 2) Representatives from the departments at the Faculty of Engineering, including the Head of the Department of Mechanical Engineering, the Secretary of the Department of Chemical Engineering, lecturers from the Department of Chemical Engineering, and the Head of the Department of Industrial Engineering, to know what preparations, in terms of English training program, the department has made towards AEC 2015.

In addition, through convenience sampling technique, questionnaires were spread to 111 alumni who work at multinational companies to identify what language skills are used by engineers at workplace and through stratified random sampling technique, questionnaires were distributed to 150 undergraduate engineering students at UI to find out the strength and weakness of their English skills as well as their knowledge on English uses in professional world. All respondents represented all departments, except the Department of Architecture, for it has a different MRA in the establishment of AEC 2015.

Once collected, the data from the interviews were qualitatively analyzed, starting from reducing the data 
and drawing conclusions, while the data from the questionnaires were analyzed using statistical counting based on the types of the questions. Furthermore, in the stage of interpreting, all data went through triangulation, which is a process which, according to Long (2005), "involves the researcher comparing different sets and sources of data with one another [...]" (p.28).

\section{RESULTS AND DISCUSSION}

Dudley-Evans and St John (1998, pp. 123-124) summarized some basic concepts of English needs. They referred to Brindley (1989: 65) with his terms "objective and subjective needs" and Berwick (1989: 55) with "perceived and felt needs". Both theorists shared similar ideas in defining those needs. Objective and perceived needs are the external factors influencing the needs apart from the learners which can be verified. These needs, for example, can be identified by the employers, the teachers, and the alumni. On the other hand, subjective and perceived needs are the internal factors of the learners which are related to cognitive and affective aspects or, in simple words, what they know and what they feel about their own needs (Dudley-Evans \& St John, 1998, pp. 123124).

The following discussion includes the results of interviews with the representatives from the two companies and the departments from the Faculty of Engineering at UI as well as the results of the questionnaires answered by the alumni. All of them serve to identify objective and perceived needs. Meanwhile, the results of the questionnaires answered by the engineering students become the pivot of the analysis on subjective and perceived needs. The findings of this study are divided into three categories of analysis, namely Target Situation Analysis, Present Situation Analysis, and Teaching Context Analysis, as adopted from Basturkmen(2010,p. 19).

\section{Target situation analysis}

According to the Head of HRD of Hitachi Asia Ltd. Jakarta Office (personal interview, 23 September 2013), English proficiency was essential and even mandatory for their employees. As a multinational company with workers from various countries, Hitachi chose English to be the daily-spoken language at their office to avoid misunderstanding among the workers, considering the fact that some expatriates were not proficient in Indonesian. English was used to carry out a range of activities, such as corresponding with Hitachi Head Quarters in Japan and Singapore, writing reports, and studying documents.

Consequently, English proficiency was placed as a crucial component of assessment when recruiting employees. She explained that those who wanted to apply for a job at Hitachi were strongly required to possess good English language ability; otherwise, they would not be accepted. She said, "At least, they are communicative. They don't necessarily have to be native-like, but at least, they can communicate well." (Personal interview,
September 23, 2013). Grammatical mistakes, for example, could be tolerated as long as the meaning conveyed by the communicator was understood by the listener. Frequently, she added, the low English proficiency of a potential employee with impressive academic records prevented him to get a job at Hitachi. Since English proficiency was a must before an applicant could be hired, the company did not provide English language training after the employee entered the workplace.

Regarding the issue of ASEAN Economic Community 2015, Takaoka said that the implementation of AEC would not bring any changes in the composition of employees at Hitachi. When recruiting employees, the nationalities of the applicants were overlooked, and the assessment was based on the individual performance during the selection process. So far, according to her evaluation, the Indonesian employees working for Hitachi were quite fluent in speaking and sharing information, a plus point of our workers.

However, she admitted that there were two language problems which repeatedly happened when communicating with Indonesian workers. The first one was grammar. Grammatical errors could be problematic when it comes to writing official documents. Although the documents were comprehensible, they could not be sent abroad. To solve this problem, the Japanese workers at Hitachi office in Jakarta would do some corrections. The second problem was pronunciation. Takaoka found that Indonesian workers still had their strong Indonesian accent when pronouncing words in English. For example, the consonant ' $r$ ' was too stressed. This problem would not really matter if they were communicating with people who were familiar with Indonesian accent. Nevertheless, Indonesian accent might not be as well-known as Singaporean or Australian accents that foreigners could be confused when speaking to an Indonesian with his or her strong local accent. Dealing with this problem, practicing to pronounce words in English might help Indonesian employees improve their English proficiency.

Quite differently, the Recruitment and Training officer of PT Wijaya Kusuma Contractors (personal communication, May 5, 2014) declared that the use of English had not been that necessary for PT Wijaya Kusuma Contractors (PT WKC), whose workers were all Indonesians and provided service merely for local clients. Hence, the English proficiency of applicants was not deemed as an important component, for PT WKC put more emphasis on their technical skills and knowledge, not to mention that English proficiency does not necessarily boost an employee's career at that company. However, PT WKC was now preparing their employees to be proficient in English by conducting English classes in two levels, which were basic and intermediate level, given to the employees after working hours with the purpose of expanding the company's scope of market and targeting projects from foreign clients. In addition, she mentioned speaking and writing skills as the most important English skills to communicate, do correspondence, and make reports. 
By comparing those two companies, it was found that there are differences and similarities between PT WKC as the example of a local company and Hitachi as the example of a multinational company. On one hand, they had different needs of English language use due to their distinctive scopes of work. That is, Hitachi considered the employees' English proficiency was essential to carry out a number of activities, while PT WKC did not use English at work or place English proficiency on top of the list of assessment components of their recruitment. This difference in needs affects whether English language training was provided for workers in respective company. On the other hand, similarities lie on the fact that both companies agreed that it was speaking and writing skills which needed to be mastered by employees although at Hitachi, reading skills as well as drills focusing on grammar and pronunciation were of the same importance.

Going further, Basturkmen (2010,p. 17) pointed out that one of the basic purposes of conducting needs analysis is to teach learners language and communication skills which are to be effectively applied in their study fields, professions, or workplaces. Thus, to get a bigger picture of the engineering students' needs in learning English for their future professional world, it is important to find out how English is used in real situation, the activities which are carried out in English, and the skills which are necessary to master to work in a multinational company, and this information was collected from testimonials from the alumni who worked at multinational companies.

Below are the results of the questionnaires given to 111 alumni from different departments and various batches (from 1986 graduates to 2013 graduates), consisting of 90 male and 21 female respondents. 104 of them lived in Indonesia, residing in the provinces of DKI Jakarta, West Java, East Java, South Sumatera, Riau, Jambi, Bali, South Kalimantan, and South Sulawesi, while 7 others worked abroad, residing in Abu Dhabi, Kuwait, Aberdeen (Scotland), Doha (Qatar), Singapore, and Germany. The items being questioned in the questionnaires for the alumni include the use of English at their workplaces, the existence of English training program from their companies, the activities they do in English at workplace, and the skills they prioritize to improve, and the existence of English training program from their departments when they were students.

In the questionnaires, $78,38 \%$ of all respondents said that they used English at their respective workplaces with the average frequency of the use of English at workplace is 4.833 hours. This affirms that English was the compulsory means of communication at companies, regardless the nationalities of the person they were talking to, even if when they were interacting with Indonesians and non-native speakers. In addition, only $18,92 \%$ of the respondents admitted that they were given English language trainings by the employers. It may mean that they were expected to be proficient in English before they were accepted as employees, just like what Hitachi HRD officers did in their recruitment. This finding may be attributed to one postulation made by Saraithong \& Chancharoenchai (2012, p. 7) saying that "according to the theory of labor marginalization, it provides undoubted solution that employers will pay at marginal productivity of labor. The better use in English is generally treated as an extra qualification for recruitment of which brings to considering of recompense."

Next, the respondents were given 17 specified activities and had to state the frequency of their doing those activities in English. The frequency was measured with five scales ("Very Frequent", "Frequent", "Sometimes", "Rarely", and "Never"), and the sum of the scores for each activity was used to put those activities in rank. The higher the total score is, the most frequent the activity is carried out in English. Based on the results, the most frequent activities done in English were reading (instructions, reports, e-mails, articles in engineering field, and official letters), writing (e-mails and reports), and speaking, especially in formal context. Besides those activities, the respondents were provided with additional space for them to write down activities that were not mentioned in the questionnaires. The most common responses here include attending and giving trainings although, depending on their respective fields of work and position, the respondents also mentioned other specified activities, such as attending meetings, writing minutes of meetings, evaluating proposals, reading signs on machines, and having briefings before carrying out collaborative tasks. One of them also mentioned talking to local people using the local language, for example, English in Singapore and German in Germany. This is in line with Riemer (2007, p. 90) who said that "multilingualism in an engineering course is increasingly focusing on regional communication skills, where the main languages from within that country's region are becoming just as important as learning English."

The respondents were then asked to put the number 1 to 13 for each skill to show what skills they prioritized to improve. These skills were derived from the four main skills in English, which are reading, listening, writing, and speaking with the addition of vocabulary. The numbers they gave for an activity were summed to get a total score which was used to put those skills in rank. The lower the total score is, the more the workers wanted to improve the skill. The results indicate that speaking, emphasized on confidence, fluency, and pronunciation, is what they wanted to improve the most. The following skills include understanding main ideas in listening, understanding main ideas in reading texts, and vocabulary mastery. It is quite astonishing, however, knowing that writing skills, which were deemed important by the companies, were not prioritized by the workers. Although the questionnaires, unfortunately, did not provide the reasons why the respondents did not prefer writing skills, that difference in responses may reveal the fact that the employers and the employees can have different perceptions on what skills are important to improve.

At this point, the study has managed to discover the 
objective and perceived needs of English teaching for engineers at workplace. Firstly, it is affirmed that English proficiency is obligatory for employees to be hired by multinational companies and to keep up with the activities carried out in English at workplace. Secondly, from the professionals' points of view, including the HRD of the companies and the alumni, the English skills needed at workplace include reading, speaking, writing, and vocabulary. According to the employers and the workers, reading is essential, for most activities done in English by the workers require this skill. In terms of speaking, pronunciation, confidence, and fluency are the most important aspects to be improved. As to writing skill, this skill also needs to be drilled, for Takaoka found it lacking from Indonesian employees. Last but not least, the needs to improve those skills were generally not accommodated by the company, particularly the multinational one. Applicants were expected to master those skills before they were accepted as employees. Thus, it can be inferred that the company left the job to the departments at the Faculty of Engineering to help the students be prepared for their professional world by facilitating them in learning those important English skills.

\section{Present situation analysis}

To be balanced in defining the needs of learning English for engineering students, the subjective and felt needs from the students' self-assessment were also identified. This section reveals the results of the questionnaires given to 150 students from different departments and batches (2009-2013), consisting of 95 male and 55 female students. The items being questioned in the questionnaires for students include the importance of English proficiency for their future career, their selfassessment of their English proficiency, the skills they prioritize to learn about, and the effective ways to learn and practice English at present times.

The findings show that students' perception on the importance of English proficiency for their future varied due to their different plans of career. For example, after they graduate, $48,67 \%$ of the respondents would like to work at multinational companies in Indonesia, 16\% would like to work abroad, $15,33 \%$ would like to work at national companies, and $14 \%$ would like to continue their study to master degree. This is similar to what Hutchinson \& Waters $(1987$, p. 8) said that "learners were seen to have different needs and interests, which would have an important influence on their motivation to learn and therefore on the effectiveness of their learning." Nevertheless, most of them, accounting for $77,33 \%$, considered English proficiency as an important and urgent matter for their future career.

The study then moves on to their self-assessment of their English skills. The purpose was to figure out their strengths and weaknesses in English proficiency. With the same 13 skills given to the alumni, they were asked to choose one of these qualitative scales: "Excellent", "Very Good", "Good", "Adequate", "Poor", and "Very Poor". To score them in number, the scales were converted to 6 ,
$5,4,3,2$, and 1 respectively. The most answers that appeared are "Good" and "Adequate", illustrating that they felt quite confident with their English proficiency. Subsequently, to know which skills they were good or weak at, the scores from every respondent for each skill were summed and ranked. The higher the score is, the more the students felt proficient in a particular English skill. The maximum score was ranked as the first, while the minimum score was ranked as the sixth. Attention was given to the bottom of the rank, which suggests that grammatical accuracy, fluency, and confidence in speaking are considered to be their weak points. In addition, 19,33\% of the students took English courses outside the class, ranging from General English to TOEFL test preparation.

The following item is about the skills they prioritize to learn about, found out using the same list of English skills with a different method of assessment. Here, the respondents were asked to put the number 1 to 13 for each skill. The numbers they gave for an activity were summed to get a total score which was used to put those skills in rank. The lower the total score is, the more the students wanted to improve the skill. The results demonstrates that speaking skills (fluency, confidence, and pronunciation), mastery of common vocabulary, and listening skills were prioritized, showing a similar result with the previous findings. It is, however, important to note that, when compared to that of the alumni's responses, the students' priorities were quite distinct. To illustrate, the alumni placed the aspect of understanding main ideas in reading on the $4^{\text {th }}$ rank, whereas students placed it on the $9^{\text {th }}$ rank. Furthermore, the alumni regarded that same aspect essential to be improved since reading was the activity most frequently carried out in English, while students did not prioritize it, for $54 \%$ of them felt they were already good at it. This difference in priority might be attributed to the notion that students based their priority on their present level of English proficiency, while alumni based their priority on their present proficiency as well as the needs at their work places.

The last item being asked was the effective ways to learn and practice English at present times, which were identified as learning needs by Dudley-Evans \& St John (1998, p. 125). The respondents were given 11 items related to learning partner, activities, and media and were asked to rate them using qualitative measures, namely "Really Suitable", "Quite Suitable", "Suitable", "Rather Not Suitable", "Not Suitable", and "Totally Not Suitable", which were converted to 6 to 1 score. The higher the total score was, the more suitable the activity was for the students in learning English. It turns out that in terms of learning partners, the respondents favored learning with a guiding teacher over learning independently, learning in a small group, and learning with another student. In terms of learning activities, they preferred doing project work which employed imagination and creativity to role-playing and problemsolving. Next, in terms of learning media, the respondents found the Internet and TV programs more suitable than video games or radio programs. 
Up to this last finding, the study has finally found out the subjective and felt needs of the students. First of all, nearly all of the students were aware that English proficiency was vital for their future career. Second, students generally felt that their level of English proficiency in most skills was either good or adequate. Third, the skills which were necessary for them to improve included speaking skill, listening skill, and vocabulary mastery. Specifically, the speaking exercise should cover fluency, confidence, and pronunciation, while the listening skill should focus on understanding main ideas. Those skills should finally be completed with mastery of common vocabularies. Fourth, learning with a guiding teacher by doing project work which involved imagination and creativity, with the help of the Internet and TV programs, was found to be the most effective and suitable way for them to learn and practice.

\section{Teaching context analysis}

The previous findings postulate the urgency of English in the engineers' professional world, as confirmed by employers, alumni, and students. This notion was later agreed by the representatives of the departments at the Faculty of Engineering, Universitas Indonesia, resulting in their taking initiatives to improve their students' English proficiency.

Being in the progress towards internationalization, the Head of the Department of Mechanical Engineering (personal interview, 20 September 2013), had encouraged the students to start learning English themselves, at least passively, by reading journals and expository written in English as their learning sources in the class. They had also persuaded students to achieve particular TOEFL score before they graduated.

A similar response came from the Department of Chemical Engineering which, based on the accounts from the Secretary of the Department of Chemical Engineering and two lecturers from the Department of Chemical Engineering (personal interviews, 20 September 2013), had run a 2-credit course titled "Communication Skills" since the year 2000. The course, regularly given to freshmen in their second semester, was provided to achieve one of their Effective Learning Outcomes (ELO), namely students' ability of communicating in English, and was comprised of both academic and professional materials, such as note-taking and job interviews, all of which were trained and taught by the department's lecturers.

As for the Department of Industrial Engineering, the Head of this department (personal interview, 30 September 2013) mentioned three initiatives. First, 7thsemester students were facilitated to take TOEFL, and the results were to be returned to them to reflect on their weaknesses. Second, three courses, which were Simulation Modelling, Total Quality Management, and Industrial Statistics, were already taught in English by lecturers graduating from universities abroad. Third, they annually held a scientific competition named Lomba
Keilmuan Teknik Industri, which started inviting foreign participants in 2014.

Despite those taken measures, responding to AEC 2015, the Head of the Department of Mechanical Engineering (personal interview, 20 September 2013) said that the Department of Mechanical Engineering did not have any special preparations in a way that there was no fundamental change in their curriculum, especially in English courses, nor specific regulation from the faculty to do so. The only subject teaching English skills was the compulsory Academic English subject, known as MPK Bahasa Inggris, from the university which was taught twice a week during the students' initial term. Additionally, although he thought that special program like English for Engineers was important for the students, he admitted that that kind of program was not really necessary due to several reasons.

First of all, he said that the students in his department had now realized that their skill in communicating in English, proven by a TOEFL score or a course certificate, could be added value for them to compete in professional world. Therefore, before they applied for a job, most of them knew they should have an English language proficiency certificate. Based on the data that the faculty has most of the graduates of the Department of Mechanical Engineering worked in oil and gas industry, manufacturing industry, and contractor consultant at multinational companies. Only few of them were willing to work in local companies or in the government.

Secondly, today's students were more proficient in English, for they took the initiative to take English courses outside campus. Even when they first enrolled at UI, the undergraduate students, particularly those coming from big cities, such as Jakarta, Bandung, and Padang, had commonly reached good level of English. Therefore, he said, "Without any special English teaching programs, the students have already been familiar with English vocabulary in their respective fields of study." Problems in language might arise from students coming from smaller regions, whose English proficiency was generally poor. The subject MPK Bahasa Inggris could be helpful, but the impacts were not that significant since they were given the course only during the first semester, and there were not any continual English learning courses either from the university or from the department. Besides, their English skills were actually needed more in higher semesters because the subjects were more specific or more skill-oriented and the students were often required to read journals and textbooks written in English. Consequently, many students from smaller cities still found difficulties in English when taking those subjects.

Thirdly, as also supported by the Secretary of the Department of Chemical Engineering, the English grammar used in engineering field was not as difficult as the English pattern used in social or economic field because the essential skill for engineers was report 
Table 1. Important English skills to teach

\begin{tabular}{|c|c|c|c|}
\hline No. & Skills & Emphases & Examples of Communication Contexts \\
\hline 1. & Speaking & $\begin{array}{l}\text { Confidence } \\
\text { Fluency } \\
\text { Pronunciation } \\
\text { Clarity }\end{array}$ & $\begin{array}{ll}\text { - } & \text { Trainings } \\
\text { - } & \text { Meeting s(giving feedback and to-the-point } \\
& \text { conclusion) } \\
\text { - } & \text { Presentations } \\
\text { - } & \text { Phone calls } \\
\text { - } & \text { Teleconferences } \\
- & \text { Intercultural communication or informal } \\
& \text { meetings }\end{array}$ \\
\hline 2. & Listening & Main ideas & $\begin{array}{ll}\text { - } & \text { Trainings } \\
\text { - } & \text { Phone conversation } \\
\text { - } & \text { Teleconferences }\end{array}$ \\
\hline 3. & Reading & Main ideas & $\begin{array}{ll}\text { - } & \text { Instructions } \\
\text { - } & \text { Emails } \\
\text { - } & \text { Reports } \\
\text { - } & \text { Articles in engineering } \\
\text { - } & \text { Official letters } \\
\text { - } & \text { Signs on machines }\end{array}$ \\
\hline 4. & Vocabulary & $\begin{array}{l}\text { General vocabulary } \\
\text { Vocabulary specialized in } \\
\text { engineering }\end{array}$ & - \\
\hline 5. & Writing & Grammatical structure & $\begin{array}{ll}- & \text { Emails } \\
- & \text { Reports } \\
- & \text { Official letters } \\
- & \text { Minutes of meetings }\end{array}$ \\
\hline
\end{tabular}

writing, whose grammar was simpler compared to other types of writings. Also, in oral communication, engineers used more numbers rather than words. Hence, even though the grammar of the engineers was not really accurate, there was no problem as long as the content of communication was understandable.

From the interviews, it can be inferred that the departments did not think to have any responsibilities to give the students an English language training for professional purposes because there was no specific regulation from the faculty and the university to do so. It is also because they considered most of the students had already been proficient, and English in engineering field was not that complex. This has then brought us to Hutchinson \& Waters (1987) who said that the focus of ESP lies not on the language use but on the language learning. Thus, the needs of using English might not always reflect the needs of learning English, as drawn from the interviews with the departments.

Nevertheless, the departments' views can also be seen as assumptive generalization, for they had not asked the students whether they needed special English courses or not. In the questionnaires, when the students were asked about whether they were willing to join a special English training program if provided by the departments, $93.33 \%$ of them said "Yes". In terms of the frequency of the course in one week, most of them $(49.29 \%)$ chose twice-a-week course. As to the duration of studying, $69.33 \%$ of them agreed that two hours was sufficient. Last but not least, regarding the teacher of the course, $72.86 \%$ of them would like to be taught by a professional English trainer although he or she might not be from their field of study, while the rest favored a lecturer from their department who had adequate level of English proficiency.

Therefore, if the Faculty of Engineering, Universitas Indonesia, is about to outperform engineers from other countries in ASEAN region, an English course specialized for professional purposes can be set up by being adjusted to the students' preference of learning activities, frequency, duration, and teachers. That kind of course is better to be an optional course, for not all of them would directly come in contact with professional world. As a recommendation, the English skills which are necessary to teach include:

\section{CONCLUSION AND RECOMMENDATION}

In brief, the results show that English proficiency was compulsory for an engineer to get a job, especially in a multinational company. Nevertheless, the needs of English language learning were regarded not significant. A win-win solution for this can be to provide an optional course on English for Professional Purposes as a 
collaboratively-taught course between English teachers or needs analysis practitioners and lecturers in engineering field. Moreover, the departments should also give information to the students about their future professional world, such as the requirements they should meet to get hired and the activities they would probably do in English. For instance, the departments can collaborate with the companies and the alumni to hold career information and sharing sessions. These efforts would be beneficial not only for the students who can be more prepared to compete in AEC 2015 but also for the departments which can increase the quality of their teaching programs and curriculum and for the companies which can recruit more qualified future engineers.

Suggestions for other researchers who are interested in this topic are to develop this study by involving more respondents or expanding the scope of the research to other fields of study related to AEC 2015 and to complete it by using another approach or other additional methods of collecting data, for example, shadowing or close observation and analysis of authentic documents.

All of the findings above were meant to be the basis of recommendations for the stakeholders at Universitas Indonesia to increase English proficiency of the Faculty of Engineering's graduates in order to outperform their competitors in ASEAN Economic Community 2015, particularly in terms of professional communication skills, and were hoped to stimulate more interdisciplinary studies in the future in tackling the same issue.

\section{REFERENCES}

Alshumaimeri, Y. (2009). Needs analysis. Retrieved January 13, 2014 from: faculty.ksu.edu.sa/yousif/Course $\% 20$ content $\% 20 \mathrm{f}$ or $\% 20 \mathrm{CI} \% 20584 / \mathrm{Needs} \% 20$ Analysis.pdf

Bahasa Inggris hambatan Indonesia ke masyarakat ekonomi ASEAN (English as a barrier for Indonesia to ASEAN economic community, translated by authors). (2013). Koran Tangerang. Retrieved April 30, 2013 from: http://korantangerang.com/?p=7947

Basturkmen, H. (2010). Developing courses in English for specific purposes. New York:Palgrave Macmillan.

Berwick, R. (1989). Needs assessment in language programming: From theory to practice. In R. K. Johnson (Ed.), The second language curriculum. Cambridge: Cambridge University Press.

Bridley, G. P. (1989). The role of needs analysis in adult ESL programme design. In R. K. Johnson (Ed.), The second language curriculum.
Cambridge: Cambridge University Press.

Ministry of trade of the Republic of Indonesia. (n.d.).

Menuju ASEAN economic community 2015

(Towards ASEAN economic community 2015, translated by authors). Retrieved April 30, 2013 from:

http://ditjenkpi.kemendag.go.id/website kpi/Umu $\mathrm{m} /$ Setditjen/Buku\%20Menuju\%20ASEĀN\%20E CONOMIC\%20COMMUNITY\%20COMMUN ITY\%202015.pdf

Dudley-Evans, T. \& St John, M. J. (1998).

Developments in English for specific purposes- $A$ multi-disciplinary approach. Cambridge: Cambridge University Press.

English First. (2012). EF English proficiency index 2012. Retrieved February 13, 2013 from: www.ef.com/epi.

Hidayat, A. S. (2008). "ASEAN economic community (AEC): Opportunities and challenges for Indonesia" (ASEAN Economic Community (AEC): Peluang dan tantangan bagi Indonesia, translated by authors). Jurnal Ekonomi dan Pembangunan, (16)2, pp. 1-3.

Hutchinson, T. \& Waters, A. (1987). English for specific purposes-A learning-centred approach. Cambridge: Cambridge University Press.

Kaewpet, C. (2009). A framework for investigating learner needs: Needs analysis extended to curriculum development. Electronic Journal of Foreign Language Teaching, 6(2), pp. 209-210, 212-214. Retrieved April 12, 2013 from: http:/eflt.nus.edu.sg/v6n22009/kaewpet.pdf

Long, M. H. (2005). Second language needs analysis. Cambridge: Cambridge University Press.

Marwan, A. (2009). ESP teaching challenges in an Indonesian vocational higher institution. The English Teacher, 38, pp. 1-12. Retrieved April 14, 2013 from http://www.melta.org.my/ET/2009/ET2009_p00 1-012.pdf

Riemer, M. J. (2007). Communication skills for the 21 st century engineer. Australia: Global Journal of Engineering Education, 11(1) pp. 89-91, 94, 98. Retrieved May 2, 2013 from: http://www.wiete.com.au/journals/GJEE/Publish/ vol11no1/Riemer.pdf

Saraithong, W. \& Chancharoenchai, K. (2012). The determinants of new coming workers' English proficiency in the ASEAN economic community: A case of Thai vocational students. The IISES International Interdisciplinary Conference, pp. 3, 7. Retrieved from http://www.iises.net/wpcontent/uploads/Palermo-papers-Saraitong.pdf 